\title{
HuKuMAN BAgI PELAKU TINDAK PIDANA Membaya LARI ANAK PEREMPUAN
}

\author{
Mustakhim Jalan Brawijaya No 21 Rt 01 Rw 03 \\ mustakhim@gmail.com Mancar Peterongan Jombang
}

\begin{abstract}
This study discusses the decision No. 09/Pid.B/2012/ PN.Mojokerto about criminal act of carrying off an under age woman without permission of her parents. In the judge's ruling, it is declared that the defendant has been proven legally and convincingly guilty of committing a criminal offense by carrying off an under age woman without permission of her parents, but only with the consent of the woman outside of marriage. The offense complain is imprisonment for 1 (one) year and 2 (two) months because the defendant violated Article 332 Paragraph (1) of the Criminal Code. In addition, the defendant is also burdened to pay court fees. In the study of Islamic criminal law, punishment for carrying off an under age woman is ta'zîr jarîmah (criminal penalty). These penalties vary and can be determined by ulil amri or government official or judge who is given authority to enforce with some considerations and other reasons in accordance with Islamic criminal law.
\end{abstract}

Keywords: Penalty, carrying off, daughter.

\begin{abstract}
Abstrak: Artikel ini membahas tentang putusan perkara Nomor 09/Pid.B/2012/PN.Mojokerto tentang tindak pidana membawa lari seorang perempuan yang belum dewasa tanpa izin orang tuanya. Dalam putusan hakim tersebut, dinyatakan bahwa terdakwa telah terbukti secara sah dan meyakinkan bersalah melakukan tindak pidana membawa lari seorang perempuan yang belum dewasa tanpa izin orang tuanya tetapi dengan persetujuan perempuan itu di luar perkawinan. Delik aduannya adalah pidana penjara selama 1 (satu) tahun 2 (dua) bulan karena perbuatan terdakwa melanggar Pasal 332 Ayat (1) KUHP. Selain itu, terdakwa juga dibebani membayar biaya perkara. Dalam kajian hukum pidana Islam, hukuman membawa lari seorang perempuan yang belum dewasa merupakan hukuman jar ta'zîr. Hukuman ini berbeda-beda, dan dapat ditentukan hukumannya oleh ulil amri atau aparat pemerintah yang diberikan wewenang untuk menyelenggarakan hukuman tersebut di mana hukumannya ringan dan beratnya dapat ditentukan oleh hakim Pengadilan Negeri Mojokerto dengan beberapa pertimbangan dan alasan-alasan lainnya sesuai dengan hukum fiqh jinâyah.
\end{abstract}

Kata Kunci: Hukuman, membawa lari, anak perempuan. 


\section{Pendahuluan}

Hukum pidana atau fiqh jinâyah merupakan bagian dari syariat Islam yang berlaku semenjak diutusnya Rasulullah saw. Oleh karenanya pada zaman Rasulullah dan Khulafa Rasyidun, hukum pidana Islam berlaku sebagai hukum publik, yaitu hukum yang diatur dan diterapkan oleh pemerintah selaku penguasa yang sah atau ulil amri.

Ada tiga bagian jarîmah yang digolongkan menurut berat ringannya hukuman yaitu; hudûd, qisâs dan ta'zîr. Ta'zîr adalah jarîmah yang belum ada ketentuan nasnya dalam al-Qur'an. Belum ditentukan seberapa kadar hukuman yang akan diterima oleh si tersangka atau si pelaku kejahatan. Jarîmah ta'zîr lebih ditekankan pada hukuman yang diberikan oleh pemerintah atau kekuasaan mutlak berada di tangan pemerintah tapi masih dalam koridor agama yang tidak boleh bertentangan dengan hukum Allah.

Dalam syariat Islam, membawa lari anak yang belum dewasa tanpa izin orang tua atau yang dikenal dalam hukum Islam dengan istilah ta'zîr merupakan perbuatan yang dilarang oleh agama. Proses pengharaman tersebut karena dapat merugikan serta dapat menimbulkan fitnah antar sesama. Karena itu, artikel ini membahas tentang hukuman bagi pelaku tindak pidana membawa lari seorang perempuan yang belum dewasa tanpa izin orang tuanya dalam putusan perkara No. 09/ Pid. B/ 2012/ PN. Mkt.

Dasar Hukum Pertimbangan Hakim dalam Putusan Perkara No. 09/ Pid. B/ 2012/ PN. Mkt. tentang Tindak Pidana Membawa Lari Anak Perempuan

Ahmad Sholeh Bin Abdulloh pada awalnya kenal dengan korban yang bernama Uswatun Hasanah mulai dari tahun 2009 sampai 2010 dan telah menjalani pacaran. Awal mulanya, terdakwa, Ahmad Sholeh, telah melamar korban, Uswatun Hasanah, tetapi tanpa ada keluarganya dan tanpa identitas sehingga orang tua korban menolaknya. Setelah itu Uswatun Hasanah lari dengan Ahmad Sholeh dengan niat akan menikah. Mereka lari ke Banten selama 1 minggu dan menjalani hubungan layaknya hubungan suami istri selama dua kali.

Setelah itu korban disuruh pulang oleh orang tua dengan tujuan akan merestui hubungan mereka tetapi pada kenyataannya Ahmad Sholeh dibawa ke kantor polisi dengan alasan membawa lari anak 
dibawah umur tanpa ijin orang tua karena korban, Uswatun Hasanah, masih berumur 17 tahun sehingga dijatuhi hukuman pelanggaran Pasal 332 Ayat (1) KUHP Undang-Undang No 8 Tahun 1981 dan dijatuhi hukuman 1 tahun 2 bulan.

Dalam putusan, hakim menyatakan terdakwa, Ahmad Sholeh Bin Abdulloh telah terbukti secara sah dan meyakinkan bersalah melakukan tindak pidana membawa lari seorang perempuan yang belum dewasa tanpa ijin orang tuanya tetapi dengan persetujuan perempuan itu diluar perkawinan. Hal tersebut adalah bagian dari delik aduan dengan pidana penjara selama 1 (satu) Tahun 2 (dua) bulan karena perbuatan terdakwa melanggar Pasal 332 Ayat (1) KUHP Undang-undang No 8 Tahun 1981. Selain terdakwa juga dijatuhi pidana, maka kepadanya harus pula dibebani untuk membayar biaya perkara sebagaimana dimaksud dalam Pasal 222 (1) KUHAP.1

Majelis hakim memberikan hukuman tersebut dengan mempertimbangkan adanya hal-hal yang memberatkan ataupun yang meringankan hukuman bagi terdakwa, yaitu:

1. Hal-hal yang memberatkan: Akibat perbuatan terdakwa, menyebabkan orang tua korban jatuh sakit, serta perbuatan terdakwa merusak masa depan korban.

2. Hal-hal yang meringankan: Terdakwa mengakui terus terang serta menyesali perbuatannya dan terdakwa bersikap sopan selama persidangan dan belum pernah dihukum.

Menimbang, bahwa pidana yang dijatuhkan pada diri terdakwa bukanlah merupakan balas dendam dari Majelis Hakim pada diri terdakwa, akan tetapi semata-mata hanya sebagai pelajaran bagi terdakwa agar selama menjalani pidananya tersebut terdakwa dapat merenungi kembali bahwa yang ia lakukan merupakan tindak pidana yang dapat dijatuhi pidana, dengan harapan setelah selesainya melaksanakan pidananya tersebut ia dapat kembali ke masyarakat serta tidak akan mengulanginya lagi.

Tindak pidana membawa lari seorang perempuan di bawah umur juga sama halnya dengan melarikan perempuan yang belum dewasa, dimana dalam hal ini yaitu membawa perempuan yang belum mencapai usia dewasa dalam kejahatan ini dinamakan dengan kejahatan schaking dimana perbuatan tersebut diatur dalam pasal 332 ayat (1) KUHP.

${ }^{1}$ Putusan Perkara No. 09/ Pid. B/ 2012/ PN.Mojokerto 
Tindak pidana ini adalah delik aduan diamana dalam pasal 332 ayat (1) ke-1 diancam hukuman maksimal 7 tahun barang siapa membawa pergi seorang perempuan yang belum dewasa tanpa dikehendaki orang tuanya atau walinya tetapi dengan persetujuan perempuan itu, baik di dalam maupun diluar perkawinan.

Pasal 332 ayat (1) ke-2 menaikkan hukuman menjadi 9 tahun jika perbuatan membawa lari perempuan dilakukan dengan tipu muslihat, kekerasan atau ancaman kekerasan, dengan maksud untuk memastikan penguasaannya atas perempuan itu, baik di dalam maupun di luar perkawinan. Dalam pasal tersebut sudah jelas tentang sanksi pidana atau ancaman hukuman bagi pelaku yang melanggar pasal tersebut diancam dengan hukuman yang telah disebutkan.

Adapun mengenai Undang-Undang No 23 Tahun 2002 Tentang Perlindungan Anak, dimana yang dimaksud di sini adalah segala kegiatan untuk menjamin dan melindungi anak dan hak-haknya agar dapat hidup, tumbuh, berkembang, dan berpartisipasi, secara optimal sesuai denagn harkat dan martabat kemanusiaan, serta mendapat perlindungan dari kekerasan dan diskriminasi.

Dalam Pasal 77 berbunyi bahwa setiap orang yang dengan sengaja melakukan tindak:

1. Diskriminasi terhadap anak yang mengakibatkan anak mengalami kerugian, baik materil maupun moril sehingga menghambat fungsi sosial; atau

2. Penelantaran terhadap anak yang mengakibatkan anak sakit atau penderitaan, baik fisik, mental, maupun sosial

3. Dipidana dengan pidana penjara paling lama liam (5) tahun dan atau denda paling banyak Rp 100.000.000 (seratus juta rupiah).

Selain itu dalam pasal 81 dijelaskan yang berbunyi: (1) setiap orang yang dengan sengaja melakukan kekerasan atau ancaman kekerasan memaksa anak melakukan persetubuhan dengannya atau dengan orang lain, dipidana dengan pidana penjara 15 (lima belas tahun) dan paling singkat 3 (tiga) tahun dan denda paling banyak Rp 300.000.000 (tiga ratus juta) dan paling sedikit Rp 60.000.000 (enam puluh juta rupiah). (2) ketentuan pidana sebagaimana dimaksut dalam ayat (1) berlaku pula bagi setiap orang yang dengan sengaja melakukan 
tipu muslihat, serangkaian kebohongan atau membujuk anak melakukan persetubuhan dengannya atau dengan orang lain. ${ }^{2}$

\section{Analisis Fiqh Jinâyah terhadap Hukuman bagi Pelaku Tindak Pidana Membawa Lari Anak Perempuan dalam Putusan Perkara No. 09/ Pid. B/ 2012/ PN.Mojokerto}

Pengertian pidana adalah suatu nestapa yang ditimpakan negara kepada orang yang telah melakukan suatu tindak pidana. Nestapa adalah sebuah rasa rasa sedih atau kesedihan. Pihak yang dapat menimpakan nestapa itu tidaklah setiap orang, tetapi adalah kewenangan dari negara untuk dapat menimpakan atau menjatuhkannya kepada orang yang melakukan tindak pidana. ${ }^{3}$

Pidana itu haruslah memberikan manfaat, sehingga memberikan preventif yang ditujukan kepada pelaku tindak pidana itu, artinya bagi pelaku tindak pidana dengan dijatuhkannya pidana, dia menjadi takut untuk melakukan lagi tindak pidana pada masa yang akan datang. Di sisi lain, manfaat pidana tersebut juga dapat mencegah masyarakat melakukan tindak pidana, artinya dengan dijatuhi pidana pada pelaku yang telah melakukan tindak pidana diharapkan orang yang tidak melakukan tindak pidana menjadi takut untuk melakukan tindak pidana. ${ }^{4}$

Di dalam fiqh jinâyah, pembahasannya menyangkut permasalahan-permasalahan seputar pelanggaran syariat dan hak asasi manusia, khususnya sesama kaum muslim. Sebab, fiqh jinâyah itu sendiri merupakan ilmu yang membahas pemahaman tentang hukum shara' yang berkaitan dengan masalah perbuatan yang dilarang (jarîmah) dan hukumannya, yang diambil dari dalil-dalil terperinci, atau dengan kata lain hukum pidana itu adalah serangkaian peraturan yang mengatur masalah tindak pidana dan hukumannya.

Pengertian fiqh jinâyah tersebut di atas sejalan dengan pengertian hukum pidana menurut hukum positif (hukum hasil produk manusia) atau undang-undang karena tujuan umumnya hampir sama, yaitu menciptakan ketenangan dan ketenteraman dalam masyarakat, sebagaimana firman Allah:

\footnotetext{
${ }^{2}$ Undang-Undang No 23 Tahun 2002 Tentang Perlindungan Aanak. www.hukumonline.com

${ }^{3}$ Burhani, Kamus Ilmiah Populer (Jombang: Lintas Media, tt), 450.

${ }^{4}$ Nasrullah, Pengantar Hukum Indonesia (Padang: Rineka Cipta, 2002), 108-109.
} 
"Hai orang-orang yang beriman, taatilah Allah dan taatilah Rasul

(Muhammad), dan ulil amri di antara kalangan kalian”. (QS. An-

Nisa': 59).

Sedangkan tujuan utama dari penerapan hukuman dalam syariat Islam mengenai jarîmah adalah:

a) Mencegah atau menahan seseorang berbuat, mengulangi dan meniru untuk melakukan jarîmah (pelanggaran pidana) dan menjauhkan seseorang dari lingkungan jarîmah perbaikan dan pendidikan.

b) Memperbaiki dan mendidik akhlak seseorang yang telah melakukan jarîmah agar berubah menjadi lebih baik dan menyadari kesalahannya. Sehingga menjauhkan manusia dari lingkungan jarîmah, dan menjadikan akhlak yang terpuji atau luhur.

Fiqh jinâyah ini mengkaji seputar permasalahan yang berkaitan dengan pelanggaran syariat dan hak asasi manusia demi menciptakan ketenangan dan ketenteraman dalam hidup bermasyarakat.

Macam-macam hukum yang masuk ke dalam pembahasan kajian fiqh jinâyah ini sangatlah banyak, yaitu semua hukum tindak pidana yang berkaitan dengan pelanggaran syariat dan hak asasi manusia dengan mengedepankan akhlah yang luhur. Secara garis besar, hukum-hukum tersebut dikelompokkan menjadi 3 macam, yaitu hukum qisâs dan diyat, hukum had atau hudûd, dan hukum ta'zîr.

Maksud pokok hukuman adalah untuk memelihara dan menciptakan kemaslahatan manusia dan menjaga mereka dari hal-hal yang mafsadah, karena Islam itu sebagai rahmah li al-âlamîn, untuk memberi petunjuk dan pelajaran kepada manusia. Hukuman itu harus mempunyai dasar, baik dari al-Qur'an, hadis, atau lembaga legislatif yang mempunyai kewenangan menetapkan hukuman untuk kasus ta'zîr. Selain itu hukuman itu harus bersifat pribadi. Artinya hanya dijatuhkan kepada yang melakukan kejahatan saja. Hal ini sesuai dengan prinsip bahwa: "Seseorang tidak menanggung dosanya orang lain". Terakhir, hukuman itu harus bersifat umum, maksudnya berlaku bagi semua orang, karena semua manusia sama di hadapan hukum.

Hal-hal yang mempengaruhi hukuman, seperti telah diketahui, pada prinsipnya al-Qur'an merupakan norma-norma dasar. Oleh karena itu, dalam menentukan hukuman, al-Qur'an memberikan pola dasar yang umum. Pemberian pola yang dasar tersebut memberikan keleluasaan bagi masyarakat untuk menyesuaikan dengan kondisi masyarakat tersebut. Namun demikian, syariat menentukan beberapa 
jenis perbuatan tertentu yangdianggap sebagai kejahatan. Jenis kejahatan yang telah ditentukan syariat dan telah ditentukan pula hukumannya itu sangat terbatas, yaitu jenis-jenis tindak pidana yang masuk dalam kelompok hudûd dan qisâs atau diyat yang jumlahnya tidak lebih dari dua belas jenis. ${ }^{5}$

Adapun selebihnya, yang merupakan bagian terbesar dari jumlah tindak pidana dan hukuman, diserahkan kepada Ulul Amri dalam menentukan jenis pelanggaran maupun hukumannya. Walaupun demikian, syariat masih menentukan beberapa di antaranya sebagai suatu kejahatan yang dapat dihukum, tanpa menentukan sanksinya. Jadi, hal ini pun merupakan pendelegasian wewenang dari pembuatsyariat kepada Ulul Amri dalam menentukan jenis hukumannya.

Kepercayaan yang diberikan pembuat syariat dalam menentukan bentuk pelanggaran dan macam hukuman tersebut ditujukan agar penguasa dapat secara leluasa mengatur masyarakatnya. Seandainya pembuat syariat menentukan semua bentuk pelanggaran dan jenis hukuman secara baku, Ulul Amri mungkin akan mendapatkan kesulitan dalam mencari kemashlahatan

bagi rakyatnya. Hal ini karena kemaslahatan berubah sesuai dengan perubahan waktu dan tempat sehingga sangat rentan terhadap perubahan. Oleh sebab itu, hanya pada hal-hal yang kebal terhadap perubahan sajalah, syariat memberikan aturan yang berlaku. Adapun tujuan pelaksanaan hukuman adalah sebagai berikut:

1. Pencegahan (al-rad' wa al-zajr)

Pengertian pencegahan adalah menahan orang berbuat jarîmah agar ia tidak mengulangi perbuatan jarîmahnya, atau agar ia tidak terus menerus melakukan jarîmah tersebut. Disamping mencegah pelaku, pencegahan juga mengandug arti mencegah orang lain selain pelaku agar ia tidak ikut-ikutan melakukan jarîmah, sebab ia bisa mengetahui bahwa hukuman yang dikenakan kepada pelaku juga akan dikenakan kepada orang lain yang juga melakukan perbuatan yang sama. Dengan demikian, kegunaan pencegahan adalah rangkap, yaitu menahan orang yang berbuat itu sendiri untuk tidak mengulangi perbuatannya, dan menahan orang lain untuk tidak berbuat seperti itu serta menjauhkan diri dari lingkungan jarîmah.

\footnotetext{
${ }^{5}$ Dzajuli, Fiqh Jinayah (Upaya Menanggulangi Kejahatan dalam Islam) (Jakarta, Raja Grafindo Persada, 2000), 25-26.
} 


\section{Perbaikan dan Pendidikan (al-islâh wa al-ta'dîb)}

Maksudnya adalah agar bisa mendidik pelaku jarîmah agar ia menjadi orang yang baik dan menyadari kesalahannya. Dengan adanya hukuman ini, diharapkan akan timbul dalam diri pelaku suatu kesadaran bahwa ia menjauhi jarîmah bukan karena takut akan hukuman, melainkan karena kesadaran diri dan kebencian terhadap jarîmah serta dengan harapan mendapat ridha Allah.

Menurut pengertian tersebut suatu perbuatan itu baru dianggap sebagai tindak pidana, apabila bertentangan dengan undang-undang dan diancam dengan hukuman. Apabila perbuatan itu tidak bertentangan dengan hukum artinya hukum tidak melarangnya dan tidak ada hukumannya dalam undang-undang maka perbuatan itu tidak dianggap sebagai tindak pidana. ${ }^{6}$

Yang dimaksud dengan hukum ta'zîr adalah hukuman atas pelanggaran yang tidak ditetapkan hukumannya dalam al-Qur'an dan hadis yang bentuknya sebagai hukuman ringan. Hukum ta'zîr diperuntukkan bagi seseorang yang melakukan jinâyah/kejahatan yang tidak atau belum memenuhi syarat untuk hukum had atau tidak memenuhi syarat membayar diyat sebagai hukum ringan untuk menebus dosanya akibat dari perbuatannya. ${ }^{\top}$

Menurut H. Moh Anwar, hukum ta'zîr ini oleh Islam diserahkan sepenuhnya kepada hakim, akan tetapi dengan memperhatikan kepada hukum-hukum pidana positif (undang-undang) juga dengan berlandaskan atau dengan didasari hukum al-Qur'an dan hadis, tidak boleh semena-mena. Maka oleh karena itu hakim berhak untuk menyusun KUH atau KUHP.

Ta'zîr ini disusun oleh suatu badan resmi yang diangkat oleh pemerintah kepala negara yang diberi tugas khusus untuk menyusunnya yang kemudian hasilnya diputuskan oleh DPR, lalu disahkan oleh kepala negara untuk dilaksanakan oleh setiap hakim dalam melaksanakan kewajibannya. ${ }^{8}$ Seperti yang telah dipaparkan sebelumnya bahwa ta'zîr menurut bahasa lafaz ta'zîr berasal dari kata 'azzara yang sinonimnya yang artinya mencegah dan menolak yang artinya mendidik.

\footnotetext{
${ }^{6}$ Ahmad Muslich Wardi, Hukum Pidana Islam (Jakarta: Sinar Grafika, 2005), 138-139.

${ }^{7}$ Abdul Qadir Audah, Al-Tashrî́al-Jinâliy al-Islâmiy (Beriut:Dâr al-Kitâb al-Arabi), 23.

${ }^{8}$ Ahmad Hanafi, Asas-Asas Hukum Pidana Islam (Jakarta: Bulan Bintang, 1967), 7-8.
} 
Pengertian tersebut sesuai dengan apa yang dikemukakan oleh Abdul Qadir Audah dan Wahbah Azzuhaily, bahwa ta'zîr diartikan mencegah dan menolak karena ia dapat mencegah pelaku agar tidak mengulangi perbuatannya lagi. Sedangkan ta'zîr diartikan mendidik karena ta'zîr dimaksudkan untuk mendidik dan memperbaiki pelaku agar Ia menyadari perbuatan jarîmahnya kemudian meninggalkan dan menghentikannya. ${ }^{9}$

Istilah jarîmah ta'zîr menurut hukum pidana Islam adalah tindakan yang berupa edukatif (pengajaran) terhadap pelaku perbuatan dosa yang tidak ada sanksi had dan kifâratnya, atau dengan kata lain, ta'zîr adalah hukuman yang bersifat edukatif yang ditentukan oleh hakim. Jadi ta'zîr merupakan hukuman terhadap perbuatan pidana/delik yang tidak ada ketetapan dalam nas tentang hukumannya. Hukuman hukuman ta'zîr tidak mempunyai batas-batas hukuman tertentu, karena shara' hanya menyebutkan sekumpulan hukuman, mulai dari yang seringan-ringannya sampai hukuman yang seberat beratnya. Dengan kata lain, hakimlah yang berhak menentukan macam tindak pidana beserta hukumannya, karena kepastian hukumnya belum ditentukan oleh shara.' ${ }^{10}$

Di samping itu juga, hukuman ta'zîr merupakan hukuman atas tindakan pelanggaran dan kriminalitas yang tidak diatur secara pasti dalam hukum had. Hukuman ini berbeda-beda, sesuai dengan perbedaan tindak pidana dan pelakunya. ${ }^{11}$ Dalam bukunya, Mahmud Syaltut (alIslâm Aqîdah wa Sharî̉ah) sebagaimana yang dikutip oleh Abdullahi Ahmed an-Na'im dikatakan bahwa, yurisprudensi Islam historis memberikan penguasa negara Islam atau hakim-hakimnya kekuasaan dan kebijaksanaan yang tersisa, apakah mempidanakan dan bagaimana menghukum apa yang mereka anggap sebagai perilaku tercela yang belum tercakup dalam kategori-kategori khusus hudûd dan jinayat. ${ }^{12}$

Suatu perbuatan baru dianggap sebagai tindak pidana apabila unsur-unsurnya telah terpenuhi. Unsur-unsur tersebut ada yang umum dan yang khusus. Unsur umum berlaku untuk semua jarîmah, sedangkan unsure khusus hanya berlaku untuk masing-masing jarîmah dan berbeda

\footnotetext{
${ }^{9}$ Abdul Qadir Audah, Al-Tashrî̀ al-Jinâ'iy al-lslâmiy, 78-80.

${ }^{10}$ Ahmad Wardi Muslich, Hukum Pidana Islam, 248-249.

${ }^{11}$ Rokhmadi, Reaktualisasi Hukum Pidana Islam Kajian Tentang Formulasi Sanksi Hukum Pidana Islam (Semarang: Departemen Agama IAIN Walisongo Semarang, Pusat Penelitian, 2005), 56.

${ }^{12}$ Abdullahi Ahmed an-Na'im, Dekonstruksi Syari'ah (Jakarta: LKIS, 2004), 194.
} 
antara jarîmah yang satu dengan yang lain. Abdul Qadir Audah mengemukakan bahwa unsur-unsur umum jarîmah ada 3 macam yaitu:

a. Unsur Formal yaitu adanya nas (ketentuan) yang melarang perbuatan dan mengancamnya dengan hukuman.

b. Unsur Material yaitu adanya tingkah laku yang membentuk jarîmah, baik berupa perbuatan nyata maupun sikap tidak berbuat.

c. Unsur Moral yaitu bahwa pelaku adalah orang yang mukallaf yakni orang yang dapat dimintai pertanggungjawaban atas tindak pidana yang dilakukannya. ${ }^{13}$

Jarîmah ta'zîr merupakan asas legalitas juga diterapkan oleh shara' pada jarîmah ta'zîr meskipun berbeda dengan penerapan pada jarîmah hudûd dan qisâs-diyat karena penerapan pada jarîmah ta'zîr diperlonggar, sebab corak jarîmah ta'zîr ini serta kemaslahatan umum menghendaki adanya pelonggaran tersebut. Sebagai akibat adanya pelonggaran ini, maka untuk jarîmah-jarîmah ta'zîr tidak perlu ada penyebutan hukuman secara tersendiri, seperti pada jarîmah hudûd dan qisâsh-diyat. Dalam hal ini seorang hakim boleh memilih sesuatu hukuman yang sesuai dengan macamnya jarîmah ta'zîr dan pembuatannya, dari kumpulan hukuman-hukuman yang disediakan untuk jarîmah ta'zîr, juga hakim (ulil amri) bisa memperingan atau memberatkan hukuman. Hukuman ta'zîr dapat dibagi 3 (tiga) yaitu:

1. Hukuman ta'zîr perbuatan maksiat:

a. Perbuatan maksiat yang dikenakan hukuman had seperti: pembunuhan, pencurian, minum-minuman keras dan lain sebagainya.

b. Perbuatan maksiat yang dikenakan hukuman kifarat, seperti: menyetubuhi istri di siang hari pada bulan Ramadhan

c. Perbuatan maksiat yang tidak dikenakan hukuman had dan kifarat, seperti: percobaan pencurian, memakan bangkai dan lain sebagainya.

2. Hukuman ta'zîr dalam rangka mewujudkan kemaslahatan umum.

3. Hukuman ta'zîr atas perbuatan-perbuatan pelanggaran (mukallaf).

Asas legalitas baru dikenal oleh hukum positif pada akhir abad Ke $18 \mathrm{M}$ sebagai hasil dari revolusi Prancis. Sebelumnya, masa tersebut para hakim bisa bertindak sekehendak hatinya dalam menentukan macamnya jarîmah dan hukumannya. Meskipun pada masa sekarang asas legalitas

\footnotetext{
${ }^{13}$ Ahmad Wardi Muslich. Hukum Pidana Islam, 17-28.
} 
itu masih dipakai, namun sudah diperlonggar, tidak seperti pada masa pertamanya yang diterapkan secara ketat. Di Indonesia asas legalitas ini masih tetap dipakai, sebagaimana yang tercantum dalam pasal 1 ayat (1) KUHP Pidana Indonesia yang berbunyi: Tiada suatu perbuatanperbuatan dapat dipidana melainkan atas kekuatan ketentuan pidana dalam perundang-undangan yang telah ada sebelum perbuatan itu terjadi.

Berdasarkan pemaparan di atas telah jelas dan sesuai dengan hadis Nabi yang berbunyi:

"Dari Bahz ibn Hakim dari ayahnya dari kakeknya, bahwa Nabi saw menahan seseorang karena disangka melakukan kejahatan". (Hadits diriwayatkan oleh Abu Daud, Turmudzi, Nasa'i, dan Baihaqi, serta dishahihkan oleh Hakim). ${ }^{14}$

Hadis ini menjelaskan tentang tindakan Nabi yang menahan seseorang yang diduga melakukan tindak pidana dengan tujuan untuk memudahkan penyelidikan. Perkataan "karena suatu tuduhan" itu menunjukkan bahwa penahanan itu disamping ada yang berstatus sebagai hukuman, juga sebagai membersihkan diri. ${ }^{15}$

Oleh karena itu, dalam putusan hakim menyatakan terdakwa, Ahmad Sholeh Bin Abdulloh telah terbukti secara sah dan meyakinkan bersalah melakukan tindak pidana membawa lari seorang perempuan yang belum dewasa tanpa ijin orang tuanya tetapi dengan persetujuan perempuan itu di luar perkawinan adalah delik aduan dengan pidana penjara selama 1 (satu) Tahun 2 (dua) Bulan karena perbuatan terdakwa melanggar Pasal 332 Ayat (1) KUHP.

Selain terdakwa juga dijatuhi pidana, maka kepadanya harus pula dibebani untuk membayar biaya perkara sebagaimana dimaksud dalam Pasal 222 (1) KUHAP dimana majelis hakim memberikan alasan terdakwa diberikan hukuman ringan karena beberapa sebab sebagaimana yang berbunyi: bahwa sebelum Majelis Hakim menjatuhkan Putusan terlebih dahulu akan mempertimbangkan adanya hal-hal yang memberatkan ataupun yang meringankan hukuman bagi Terdakwa, yaitu:

\footnotetext{
${ }^{14}$ Teuku Muhammad Hasbi Ash-Shiddieqy, Koleksi Hadis-Hadis Hukum, Juz IX (Semarang: Pustaka Rizki Putra, 200)1, 202.

${ }^{15}$ Mu'ammal Hamdy, Nail al-Autâr, Juz VI (Surabaya: Bina Ilmu, 2005), 2662-2663.
} 
1. Hal-hal yang memberatkan: Akibat perbuatan terdakwa, menyebabkan orang tua korban jatuh sakit, serta perbuatan terdakwa merusak masa depan korban.

4. Hal-hal yang meringankan: Terdakwa mengakui terus terang serta menyesali perbuatannya dan terdakwa bersikap sopan selama persidangan dan belum pernah dihukum.

Menimbang, bahwa pidana yang dijatuhkan pada diri terdakwa bukanlah merupakan balas dendam dari Majelis Hakim pada diri terdakwa, akan tetapi semata-mata hanya sebagai pelajaran bagi terdakwa agar selama menjalani pidananya tersebut terdakwa dapat merenungi kembali bahwa yang ia lakukan merupakan tindak pidana yang dapat dijatuhi pidana, dengan harapan setelah selesainya melaksanakan pidananya tersebut ia dapat kembali ke masyarakat serta tidak akan mengulanginya lagi. Adapun perbuatan tersebut dapat dijatuhi hukuman ringan berdasarkan sabda Nabi yang berbunyi:

"Dari 'Aisyah bahwasanya Nabi saw bersabda: "Ampunkanlah gelinciran orang-orang yang baik-baik kecuali had-had". ${ }^{16}$

Tujuan penentuan hukuman bagi terdakwa oleh pihak Pengadilan Negeri Mojokerto mempunyai tujuan sama halnya dengan tujuan hak penentuan jarîmah ta'zîr dan hukumannya diberikan kepada penguasa.

Ulil amri adalah, supaya mereka dapat mengatur masyarakat dan memelihara kepentingan-kepentingannya, serta bisa menghadapi dengan sebaik-baiknya setiap keadaan yang bersifat mendadak. Penulis menyimpulkan perbedaan hukuman antara tiga jenis jarîmah di atas adalah jarîmah hudûd dan qisâs, hukuman tidak bisa terpengaruh oleh keadaan-keadaan tertentu yang berkaitan dengan pelaksanaan jarîmah, kecuali apabila pelaku tidak memenuhi syarat-syarat taklif, seperti gila, atau di bawah umur. Akan tetapi hal ini berbeda dalam jarîmah ta'zîr, keadaan korban atau suasana ketika jarîmah itu dilakukan dapat mempengaruhi berat ringannya hukuman yang akan dijatuhkan kepada si pelaku. ${ }^{17}$

Oleh karena itu jarîmah ta'zîr adalah jarîmah yang diancam dengan hukuman ta'zîr. Pengertian ta'zîr menurut bahasa ialah ta'dib atau memberi pelajaran. Menurut istilah, ta'zîr adalah hukuman

\footnotetext{
${ }^{16}$ Al-Asqalany lbnu Hajar, Bul - $\quad$ (Bandung: Diponegoro 2002), 576-577.

${ }^{17}$ Ahmad Wardi Muslich, Pengantar dan Asas Hukum Pidana Islam (Jakarta: Sinar Grafika, 2004), 21.
} 
pendidikan atas dosa (tindak pidana) yang belum ditentukan hukumannya oleh syara. Secara ringkas dapat dikatakan bahwa hukuman ta'zîr itu adalah hukuman yang belum ditetapkan oleh shara' melainkan diserahkan kepada hakim, baik penentuan maupun pelaksanaannya.

Dalam menentukan hukuman tersebut, hakim hanya menetapkan secara global saja. Artinya pembuat undang-undang tidak menetapkan hukuman untuk masing-masing jarîmah ta'zîr, melainkan hanya menetapkan sekumpulan hukuman, dari yang seringan-ringannya sampai seberat-seberatnya. Dengan demikian ciri khas jarîmah ta'zîr adalah sebagai berikut:

1. Hukumannya tidak tertentu dan tidak terbatas, artinya hukuman tersebut belum ditentukan oleh syara' dan ada batas minimal dan ada batas maksimal.

2. Penetapan hukuman tersebut adalah hak hakim. ${ }^{18}$

Bisa dikatakan pula, bahwa ta'zîr adalah suatu jarîmah yang diancam dengan hukuman ta'zîr (selain had dan qisâs diyat). Pelaksanaan hukuman ta'zîr, baik yang jenis larangannya ditentukan oleh nas atau tidak, baik perbuatan itu menyangkut hak Allah atau hak perorangan, hukumannya diserahkan sepenuhnya kepada hakim. Hukuman dalam jarîmah ta'zîr tidak ditentukan ukurannya atau kadarnya, artinya untuk menentukan batas terendah dan tertinggi diserahkan sepenuhnya kepada hakim (penguasa). Dengan demikian, syariah mendelegasikan kepada hakim untuk menentukan bentuk-bentuk dan hukuman kepada pelaku jarîmah.

Selain itu dalam perbuatan terdakwa juga menggunakan tipu muslihat atau serangkaian kebohongan atas anak di bawah umur dalam hal ini yaitu serangkaian cerita dari korban dan terdakwa menyetujuinya. Di mana terdakwa dengan sengaja melakukan tipu muslihat, serangkaian kebohongan atau membujuk anak melakukan persetubuhan dengannya seperti dalam pasal 81 ayat (2).

Dalam Perbuatan tindak pidana tersebut perbuatan terdakwa telah melanggar asusila dimana antara terdakwa dan Siti Uswatun Hasanah telah melakukan hubungan layaknya suami istri sebeluma akad pernikahan dimana dalam hukum Islam dikenal dengan perbuatan zina yaitu zina gair muhsan karena perbuatan tersebut anatara terdakwa dan

${ }^{18}$ Djazuli, Fiqh Jinayat Menanggulangi Kejahatan dalam Islam (Jakarta: PT Raja Grafindo Persada, 2000), 89. 
koban sama-sama belum ada ikatan pernikahan dengan orang lain. Dalam hukum Islam perbuatan zina yaitu ada 2 zina muhson (zina yang dilakukan dengan adanya ikatan pernikahan dengan orang lain) dan zina gair muhsan (perbuatan zina yang dilakukan tanpa adanya ikatan pernikahan dengan orang lain).

Mengenai sanksi tentang perbuatan zina yang dilakukan terdakwa dengan korban yaitu telah dijelaskan berdasarkan firman Allah dibawah ini, yaitu zina didera atau cambuk seratus kali adalah firman Allah dalam surat al-Nur ayat 2 yang artinya:

"Pezina perempuan dan laki-laki hendaklah dicambuk seratus kali dan janganlah merasa belas kasihan kepada keduanya sehingga mencegah kamu dalam menjalankan hukum Allah, hal ini jika kamu beriman kepada Allah dan hari akhir. Dan hendaklah dalam menjatuhkan sanksi (mencambuk) mereka disaksikan oleh sekumpulan orang-orang yang beriman. ${ }^{19}$

Inilah yang dimaksudkan al-Qur'an agar manusia bukan sekedar terlarang melakukan perzinahan akan tetapi proses yang mendorong ke arah perzinahan (senggama di luar nikah) juga dilarang, karena tahu persis bagaimana karakter seksualitas manusia yang sebenarnya:

"Dan janganlah kamu mendekati zina, sesungguhnya zina itu adalah suatu perbuatan yang keji dan suatu jalan yang buruk." ${ }^{20}$

Begitu bahayanya tindak kejahatan zina ini, sampai-sampai alQur'an memperhatikannya secara khusus, sebab perbuatan ini sangat popular di kalangan jahiliyah, sebagaimana halnya minum khamr, sehingga pelarangannya pun dilakukan secara bertahap. ${ }^{21}$ Menurut kebanyakan ulama fiqh, penetapan hukuman zina itu secara bertahap, Sedangkan dasar penetapan hukum rajam adalah hadis Nabi yang artinya:

"Terimalah dariku! Terimalah dariku! Sungguh Allah telah member jalan kepada mereka. Bujangan yang berzina dengan gadis dijilid seratus kali dan diasingkan selama satu tahun. Dan orang yang telah kawin yang berzina didera seratus kali dan dirajam". 22

\footnotetext{
${ }^{19}$ Departemen Agama Rl, Al-Qur'an dan Terjemahan (Jakarta: Proyek Pengadaan Kitab Suci AlQur'an, 1978), 141.

${ }^{20}$ Soenarjo, Al-Qur'an dan Terjemahannya (Jakarta: Departemen Agama, 1992), 542.

${ }^{21}$ Sayyid Sabiq, Fiqh al-Sunnah (Beirut: Dâr al-Fikr, 1981), jilid 2, 343.

${ }^{22}$ Imam an-Nawawi, Sahîh Muslim bi Sharh an-Nawawiy (Beirut: Dâr al-Fikr.), 180.
} 
Dari definisi tersebut dapat kita kemukakan bahwa hukuman merupakan balasan yang setimpal atas perbuatan pelaku kejahatan yang mengakibatkan orang lain menjadi korban akibat perbuatannya. Adapun dasar penjatuhan hukuman tersebut antaranya Q.S. Shad ayat 26 yang artinya:

...Hai Daud, sesungguhnya Kami menjadikan kamu khalifah (penguasa) di muka bumi, Maka berilah keputusan (perkara) di antara manusia dengan adildan jangalah kamu mengikuti hawa nafsu, karena ia akan menyesatkan kamu dari jalan Allah. Sesungguhnya orang-orang yang sesat dari jalan Allah akan mendapat adzab yang berat, karena mereka melupakan hari perhitungan. ${ }^{23}$

Dalam hukum Islam, sejak abad ketujuh masehi, perbuatanperbuatan tersebut sudah dilarang secara tegas, karena teramat jelas pula kemadaratannya. ${ }^{24}$ Kenyataan-kenyataan ini sebenarnya jelas memperkuat andangan syariat Islam, bahwa zina bukan hanya urusan pribadi yang menyinggung hubungan individu semata-mata, melainkan pula mempunyai dampak negatif bagi masyarakat. Oleh karena itu, sungguh tepatlah apabila syariat Islam melarang semua bentuk perbuatan zina, baik yang dilakukan oleh gadis dengan jejaka secara sukarela, maupun oleh orang-orang yang sudah bersuami atau beristeri. ${ }^{25}$

\section{Simpulan}

Bahwa dalam putusan hakim menyatakan terdakwa Ahmad Sholeh Bin Abdulloh telah terbukti secara sah dan meyakinkan bersalah melakukan tindak pidana membawa lari seorang perempuan yang belum dewasa tanpa izin orang tuanya tetapi dengan persetujuan perempuan itu diluar perkawinan adalah delik aduan dengan pidana penjara selama 1 (satu) Tahun 2 (dua) Bulan karena melanggar Pasal 332 Ayat (1) KUHP majelis hakim memberikan alasan terdakwa diberikan hukuman ringan karena beberapa sebab yitu 1 tahun 2 bulan.

Bahwa hukuman membawa lari seorang perempuan yang belum dewasa merupakann hukuman jarîmah ta'zîr di mana hukuman ta'zîr merupakan hukuman atas tindakan pelanggaran dan kriminalitas yang

\footnotetext{
${ }^{23}$ Soenarjo, Al-Qur'an dan Terjemahannya, 736.

${ }^{24}$ Neng Djubaedah, Fornografi \& Fornoaksi Ditinjau dari Hukum Islam (Jakarta: Prenada Media, 2003), 2.

${ }^{25}$ Ahmad Muslich Wardi, Hukum Pidana Islam, 343.
} 
tidak diatur secara pasti dalam hukum had. Hukuman ini berbeda-beda, dan dapat ditentukan hukumannya oleh ulil amri atau aparat pemerintah yang diberikan wewenang untuk menyelenggarakan hukuman tersebut dimana hukumannya ringan dan beratnya dapat ditentukan oleh hakim Pengadilan Negeri Mojokerto dengan beberapa pertimbangan dan alasan-alasan lainnya sesuai dengan hukum fiqh jinâyah.

\section{Daftar Rujukan}

Abdullah, Musthafa. Intisari Hukum Pidana. Jakarta: Ghalia Indonesia, 1983.

Ali, Zainuddin. Hukum Pidana Islam. Jakarta: Sinar Grafika, 2007.

Amir, Abd al-Aziz. Al-Ta'zîr fi al-Sharîah. Mesir: Dâr al-Fikr al-Arabi, 1969.

Arif Faizal, Enceng. dan Mubarok Jaih. Kaidah Fiqh Jinâyah Asas-Asas Hukum Pidana Islam. Bandung: Pustaka Bani Quraisy, 2004.

Ash-Shan'ani. Subul al-Salâm. Surabaya: Al-Ikhlas, 2000.

Ash-Shiddieqy, Teuku Muhammad Hasbi. Koleksi Hadis-Hadis Hukum Juz IX. Semarang: Pustaka Rizki Putra, 2001.

Asqalany (al-), Ibnu Hajar. Bulûg al-Marâm. Bandung: Diponegoro, 2002.

Audah, Abdul Qadir. al-Tashrî̀ al-Jinâ'iy al-Islâmiy. Beirut: Dar Al Kitab Al Araby, 2000.

Bahreisj, Hussein. Hadits Shahih Muslim 3. Jakarta: Widjaya, 1983.

Djazuli. Fiqh Jinayat Menanggulangi Kejahatan dalam Islam. Jakarta: Raja Grafindo Persada, 2000.

Fauzan (al-), Saleh. Al-Mulakhkhas al-Fiqh. Jakarta: Gema Insani, 2005.

Hakim, Rahmat. Hukum Pidana Islam. Bandung: Pustaka Setia, 2010.

Hamdy, Mu’ammal. Nail al-Autâr. Surabaya: Bina Ilmu, 2005.

Hanafi, Ahmad. Asas-Asas Hukum Piana Islam. Jakarta: Bulan Bintang, 1967.

Jaziri (al-), Abdurrahman. al-Fiqh 'Alâ al-Madhâhib al-'Arba'ah Jilid V. Beirut: Dar Al-Fikr Al-'Arabi, 1989.

Jufri (al-), Salim Segaf. Penerapan Syariat Islam di Indonesia. Jakarta: Global Media Cipta Publishing, 2004. 
Khallaf, Abdul Wahab. Ilmu Usul al-Fiqh. Beirut: Dâr Al Kuwaitiyah, 1968.

Mawardi (al-), Abu Al-Hasan Ali. Kitâb Al-Ahkâm As-Sultâniyah. Beirut: Dar Al-Fikr, 1996.

Muslich, Ahmad Wardi. Pengantar dan Asas Hukum Pidana Islam. Jakarta: Sinar Grafika, 2004.

Na'im (an-), Abdullahi Ahmed. Dekonstruksi Syari'ah. Jakarta: LKIS, 2004.

Nasrullah. Pengantar Hukum Indonesia. Padang: Rineka Cipta, 2002.

Ramulyo, Moh. Idris. Asas-Asas Hukum Islam. Jakarta: Sinar grafika, 2004.

Rokhmadi. Reaktualisasi Hukum Pidana Islam Kajian Tentang Formulasi Sanksi Hukum Pidana Islam. Semarang: Departemen Agama IAIN Walisongo Semarang, Pusat Penelitian, 2005.

Sabiq, Sayid. Fiqh As Sunnah. Jakarta: Sinar Grafika, 1980.

Zuhaili, Wahbah. Al-Fiqh Al-Islami Wa Adillatuhu Juz VI. Damaskus: Dar Al-Fikr, 1989.

http://www.fkip-uninus.org/index.php/artikel-fkip-uninusbandung/arsip-artikel/70-fiqih-jinayah

www.hukumonline.com diunduh pada tanggal 30 Nopember 2012 